\title{
ARTICLE
}

\section{Perinatal survivin is essential for the establishment of pancreatic beta cell mass in mice}

\author{
X. Wu $\cdot$ L. Wang $\cdot$ S. Schroer $\cdot$ D. Choi $\cdot$ P. Chen • \\ H. Okada $\cdot$ M. Woo
}

Received: 3 June 2009 / Accepted: 19 June 2009/Published online: 31 July 2009

(C) Springer-Verlag 2009

\begin{abstract}
Aims/hypothesis Pancreatic beta cells undergo dynamic remodelling during the perinatal period, with enhanced neogenesis, proliferation and apoptosis observed. The molecular mechanisms responsible for these processes have yet to be elucidated. Survivin is an inhibitor of apoptosis, first described as being exclusively expressed in tumour and embryonic tissues with regulatory functions in mitosis
\end{abstract}

Electronic supplementary material The online version of this article (doi:10.1007/s00125-009-1469-6) contains supplementary material, which is available to authorised users.

X. Wu $\cdot$ S. Schroer $\cdot$ D. Choi $\cdot$ M. Woo $(\bowtie)$

Ontario Cancer Institute,

610 University Avenue, Room 8-113,

Toronto, ON M5G 2M9, Canada

e-mail: mwoo@uhnres.utoronto.ca

$\mathrm{X} . \mathrm{Wu}$

Department of Endocrinology, First Affiliated Hospital,

Nanjing Medical University,

Nanjing, People's Republic of China

L. Wang $\cdot$ P. Chen $\cdot$ M. Woo

Department of Medical Biophysics, Ontario Cancer Institute,

University of Toronto,

Toronto, ON, Canada

H. Okada

Division of Signaling Biology Ontario Cancer Institute,

Toronto, ON, Canada

M. Woo

Department of Medicine, St Michael's Hospital,

Toronto, ON, Canada

M. Woo

Keenan Research Centre in the Li Ka Shing Knowledge Institute,

Toronto, ON, Canada and apoptosis. The aim of the present study was to define the essential physiological role of survivin in the pancreas. Methods The expression profile of survivin was assessed in the mouse pancreas, and we generated a $P d x 1$ promoterdriven Survivin (also known as Birc5) knockout mouse using the Cre-loxP recombination system to determine the essential physiological function of survivin in the pancreas. Results Survivin is transiently expressed in mouse pancreatic islets during the embryonic and neonatal periods. Targeted deletion of Survivin in the pancreas resulted in a significant decline in beta cell mass throughout the perinatal period, leading to glucose intolerance in the adult. Survivin-deficient islets showed decreased cell proliferation as a result of a delay in cell cycle progression with perturbations in cell cycle proteins. Survivin did not, however, play an essential role in beta cell apoptosis either during the physiological remodelling period or in response to streptozotocin. Islet development, islet architecture, microvasculature and apoptosis were not affected by the absence of survivin in the pancreas.

Conclusions/interpretation Survivin expression in the pancreatic islets during the perinatal remodelling period is essential for the establishment of beta cell mass through cell cycle regulation.

Keywords Beta cell mass · Diabetes · Cre-loxP. Gene knockout · IAP · Neonatal remodelling · Survivin
Abbreviations
AKT V-akt murine thymoma viral oncogenes
BAD Bcl2-associated death promoter
BCL-XL B-cell lymphoma-extra large
CDK Cyclin-dependent kinase
E Embryonic day
ERK1/2 Extracellular signal-regulated kinase 1 and 2 
GLP1 Glucagon-like peptide-1

GSIS Glucose-stimulated insulin secretion

HBSS Hanks' balanced salt solution

IAP Inhibitor of apoptosis

IPGTT Intraperitoneal glucose tolerance test

ITT Insulin tolerance test

MLDS Multiple low doses of streptozotocin

mTOR Mammalian target of rapamycin

P Postnatal day

PDX1 Pancreatic-duodenal homeobox 1

RB Retinoblastoma protein

Fl Flox

\section{Introduction}

Pancreatic beta cell mass plays an essential role in glucose homeostasis. Beta cells are dynamic and undergo slow turnover throughout the life of the organism, responding to metabolic alterations and demands by proliferation, neogenesis or apoptosis [1-3]. During embryogenesis, the murine pancreas undergoes two waves of endocrine cell differentiation [4], the first of which gives rise to glucagon-positive, insulin-positive and double-positive cells between embryonic day (E)9.5 and 13.5. The second wave of endocrine differentiation begins at approximately E13.5 and yields endocrine cells that develop to mature islets. From E18.5 to immediately after birth, beta cells undergo a transient burst of proliferation (by approximately $10 \%$ per day in mice) to rapidly increase beta cell mass $[3,5,6]$. This is followed by substantial remodelling of beta cell mass in the neonatal period, with increased beta cell apoptosis and neogenesis, and a progressive decrease in beta cell replication [1,3]. During adulthood, the beta cell population has a slow turnover rate (1-4\% per day) [7]. New beta cells are primarily formed through the replication of pre-existing mature beta cells $[8,9]$. The difference observed in the rates of beta cell proliferation at these time points is thought to be due to differences in the percentage of beta cells recruited for entry into the cell cycle. The mechanism by which more beta cells are recruited for entry into the cell cycle during embryonic vs postnatal and adult stages is currently unknown.

SURVIVIN (also known as BIRC5) is the smallest member of the inhibitor of apoptosis (IAP) gene family [10]. Initially, SURVIVIN was described as an anti-apoptosis gene [11]. However, further studies have revealed that survivin is a multifunctional protein that intersects fundamental networks of cellular processes, including cell death, cell division and cellular adaptation [12-14]. SURVIVIN has generated considerable interest in oncology research because of its overexpression in all human cancers. In addition, Survivin is expressed ubiquitously during fetal development and in some highly proliferative adult tissues, including basal colonic epithelium and $\mathrm{CD} 34^{+}$haematopoietic progenitors [13]. Germline deletion of Survivin leads to early embryonic lethality at E3.5 [15]. Tissue-specific knockout of Survivin in thymocytes, neuronal precursors, endothelial cells or haematopoietic progenitors resulted in impaired cell proliferation, cell cycle arrest, mitotic spindle defects or apoptosis, all illustrating a physiological role for survivin in normal cell development [16-19].

Previous studies have shown that SURVIVIN is expressed in islets of human fetal pancreas [20, 21]. However, the significance of the physiological expression of SURVIVIN in the pancreas was unclear. In the current study, we show that Survivin is transiently expressed in pancreatic islets during embryogenesis and the neonatal period in mice. Based on the multiple functions of survivin in cellular homeostasis, we hypothesised that survivin would be important in remodelling and establishment of pancreatic beta cell mass. To investigate the role of survivin in pancreatic beta cells in vivo, we generated a $P d x l$ promoter-driven Survivin knockout mouse.

\section{Methods}

Mice Survivin ${ }^{\mathrm{f} / \mathrm{fl}}$ mice [16], were mated with $\mathrm{Pdxl} \mathrm{Cre}^{+}$ transgenic mice [22] to generate $\mathrm{Pdxl} \mathrm{Cre}^{+}$Survivin $^{+/+}, \mathrm{Pdxl}$ $\mathrm{Cre}^{+}$Survivin $^{+/ \mathrm{fl}}$ and Pdxl Cre Survivin $^{\mathrm{f} / \mathrm{fl}}$ mice. Only littermates were used as controls. Genotypes for the Cre and Survivin genes were determined by PCR using tail DNA. PCR primers for Survivin (GeneID: 11799) were as follows: forward 5'-TGAGTCGTCTTGGCGGAGGTTGT-3', reverse 5'-GCTCGTTCTCGGTAGGGCAGTGG-3'. PCR reactions were carried out at $95^{\circ} \mathrm{C}$ for $15 \mathrm{~min}$, followed by 35 cycles of $1 \mathrm{~min}$ at $94^{\circ} \mathrm{C}, 1 \mathrm{~min}$ at $60^{\circ} \mathrm{C}, 1 \mathrm{~min}$ at $72^{\circ} \mathrm{C}$, with a final extension of $10 \mathrm{~min}$ at $72^{\circ} \mathrm{C}$. All mice were maintained on a C57BL/6 background, housed in a pathogen-free facility on a $12 \mathrm{~h}$ light/dark cycle, and had free access to standard irradiated rodent chow (5\% fat; Harlan Tecklad, Indianapolis, IN, USA), in accordance with the Ontario Cancer Institute Animal Care Facility protocol, without restriction on animal activity.

Metabolic studies and hormone measurements All overnight fasts were carried out between 17:00 hours and 10:00 hours. Blood glucose levels were determined from tail venous blood using an automated glucometer (One Touch II; Lifescan, Milpitas, CA, USA). Intraperitoneal glucose tolerance tests (IPGTT), insulin tolerance tests (ITT) and glucosestimulated insulin secretion (GSIS) tests were performed as previously described [23]. Serum insulin levels were measured by ELISA with rat insulin standards (Crystal Chem, Downers Grove, IL, USA). 
Islet isolation Pancreatic islets were isolated from 2- to 3 -week-old mice by injecting collagenase $(3 \mathrm{mg} / \mathrm{ml}$; SigmaAldrich, Oakville, ON, Canada) into the pancreas. The pancreas was then allowed to digest in the collagenase solution at $37^{\circ} \mathrm{C}$ with shaking for $15-20 \mathrm{~min}$. The digestion was stopped by ice-cold Hanks' balanced salt solution (HBSS) containing 10\% (vol./vol.) FCS. Islets were then hand-picked under a dissecting microscope.

Western blotting Islet, liver and kidney protein lysates were obtained as previously described [24]. Lysates were separated by SDS-PAGE and immunoblotted with antibodies against survivin (Novus Biologicals, Littleton, CO, USA), CyclinD1, v-akt murine thymoma viral oncogenes (AKT), phosphorylated AKT (Ser473), extracellular signal-regulated kinase 1 and 2 (ERK1/2), phosphorylated ERK1/2, mammalian target of rapamycin (mTOR), phospho-mTOR, Bcl2associated death promoter (BAD), phosphorylated BAD, B-cell lymphoma-extra large (BCL-XL), cleaved caspase-3 (Asp175) and glyceraldehyde phosphate dehydrogenase (Cell Signaling Technology, Beverly, MA, USA), phosphorylated retinoblastoma protein $(\mathrm{RB})$, cyclin-dependent kinase 2 (CDK2), p21 and caspase-3 (BD Pharmingen, San Diego, CA, USA), cyclin-dependent kinase 4 (CDK4), cyclin-E and p27 (Santa Cruz Biotechnology, Santa Cruz, CA, USA), Aurora B kinase (Abcam, Cambridge, MA, USA). Densitometric quantification of protein bands was performed using Image $\mathrm{J}$ software version 1.37 (http://rsb.info.nih.gov/ij/, accessed 14 July 2009). Samples were normalised to GADPH.

Immunohistochemistry, immunofluorescent staining and islet morphometry Pancreases were fixed for $24 \mathrm{~h}$ in $4 \%$ (wt./vol.) paraformaldehyde. Samples were dehydrated and prepared as paraffin blocks. Serial $7 \mu \mathrm{m}$ thick pancreatic sections were obtained, with at least three levels per slide, separated by $100-150 \mu \mathrm{m}$ intervals, and stained with haematoxylin and eosin, insulin (Dako, Mississauga, ON, Canada), and PDX1 (gift from C. Wright, Vanderbilt University Medical School, Department of Cell Biology, Nashville, USA), GLUT2 (Chemicon, Temecula, CA, USA). Islet microvasculature was detected using anti-von Willebrand factor (Dako, Mississauga, ON, Canada). Islet beta cell proliferation was assessed by Ki67 (Dako) and insulin staining on consecutive sections. Islet beta cell apoptosis was detected by insulin and TUNEL co-staining using the Roche (Laval, Quebec, Canada) In Situ Cell Death Detection Kit. Immunofluorescent staining was performed using antibodies against insulin, glucagon (NovoCastra Laboratories, Newcastle upon Tyne, UK) and survivin, and slides were examined using a Zeiss inverted fluorescent microscope (Advanced Optical Microscopy Facility, Ontario Cancer Institute, Toronto, ON, Canada). Total beta and alpha cell masses were determined on insulin-stained and glucagon- stained sections, respectively, and calculated by multiplying the pancreatic weight by the ratio of beta or alpha cell area to total pancreatic area. Beta cell number and size were calculated on insulin-stained sections.

Flow cytometry Freshly isolated pancreatic islets were dispersed with $0.05 \%$ (wt./vol.) trypsin-EDTA (GIBCO) and fixed in $80 \%$ (vol./vol.) ethanol. Pellets were resuspended in PBS containing propidium iodide and RNaseA (Fisher Scientific, Nepean, ON, Canada). Cell cycle analyses were performed with a Coulter EPICS XL flow cytometer (Applied Molecular Profiling Laboratory, Ontario Cancer Institute, Toronto, ON, Canada).

Exendin-4 protocol Synthetic exendin-4 was dissolved in PBS and was administered to 2-week-old mice by i.p. injection twice daily for 3 days at a dose of $24 \mathrm{nmol} / \mathrm{kg}$ body weight [25]. Age-matched PBS-injected mice were used as controls. Pancreases were analysed for changes in cell proliferation on Ki67-stained sections.

Streptozotocin protocol Multiple low doses of streptozotocin (MLDS, $40 \mathrm{mg}$ streptozotocin/kg body weight) were injected into 2-week-old Pdxl $\mathrm{Cre}^{+}$Survivin $^{+/+}$and $\mathrm{Pdxl}$ $\mathrm{Cre}^{+}$Survivin $^{\mathrm{fl} / \mathrm{fl}}$ mice for 5 consecutive days, as previously described [26]. Age-matched citrate buffer-injected mice were used as controls. Tail vein glucose was monitored weekly after streptozotocin treatment, and pancreases were examined for changes in beta cell apoptosis by immunofluorescent co-staining of insulin and TUNEL.

Statistical analysis Data are presented as means \pm SEM and were analysed by one-sample Student's $t$ test, independent samples Student's $t$ test, and one-way ANOVA with the post hoc Tukey test to determine significance. All data were analysed using the SPSS statistical software package (version 11.0) for Macintosh (SPSS, Chicago, IL, USA).

\section{Results}

Survivin is transiently expressed in mouse pancreas during the embryonic and neonatal periods Previous reports showed survivin to be present in both mouse and human pancreatic islets during embryonic development [20]. However, postnatal expression of survivin was unknown. We examined the pattern of survivin levels in mouse pancreas during embryogenesis and after birth. At E15.5, survivin was readily detected in the pancreas, which persisted until postnatal week 3 (Fig. 1a). A significant decline in survivin levels was observed from E15.5 to E18.5. This decline was followed by a rise at postnatal day (P) 1, which was then 
a

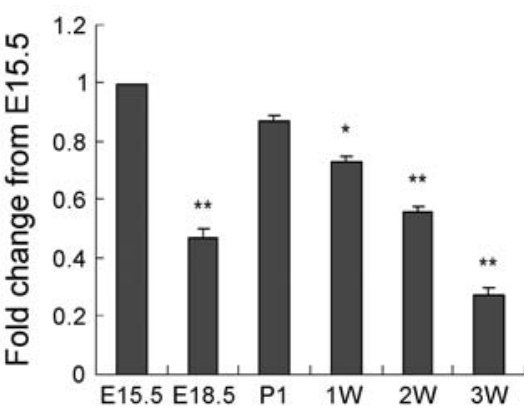

b

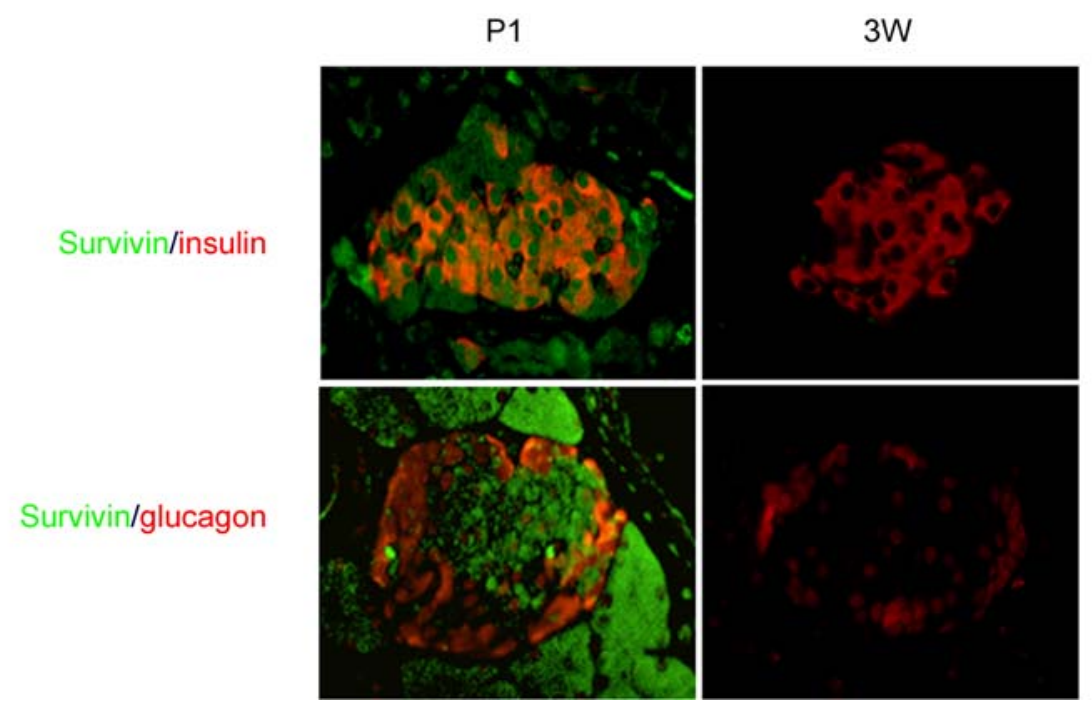

Fig. 1 Transient production of survivin in mouse pancreas during embryonic and neonatal periods. a Western blots show that survivin is readily detected in the pancreas of wild-type mice from E15.5 to postnatal week $3(3 \mathrm{~W})$, and becomes undetectable in the isolated islets by $3 \mathrm{~W}$ and in the whole pancreas by 2 months of age $(n \geq 3$ at each

followed by a gradual decline during the neonatal period between P1 and postnatal week 3 , and survivin finally became undetectable by the time the mice were 2 months of age (Fig. 1a). Immunofluorescent staining showed that survivin was present in both beta and alpha cells within pancreatic islets at $\mathrm{P} 1$, but was absent in islets by postnatal week 3 (Fig. 1b). This was further confirmed by the presence of decreased levels of survivin in isolated islets between postnatal weeks 2 and 3 according to western blot analyses (Fig. 1a).

Generation of pancreas-specific survivin-deficient mice To determine the essential role of survivin in the developing pancreas, Survivin ${ }^{\mathrm{fl} / \mathrm{fl}}$ mice [16] were crossed with $P d x 1 \mathrm{Cre}^{+}$ mice [22]. The resultant $P d x 1 \mathrm{Cre}^{+}$Survivin $^{\mathrm{fl} / \mathrm{fl}}$ mice had Survivin deleted from $P d x 1$-expressing cells. $P d x 1$ is expressed throughout the pancreatic buds as early as E9.5, and expression later becomes mainly restricted to beta cells $[27,28]$. We observed efficient deletion of Survivin both in the whole pancreas and the islets (Fig. 2a, b). PCR analysis time point). b Immunofluorescent staining shows that survivin is present in both beta and alpha cells within pancreatic islets at P1, but is absent in islets by $3 \mathrm{~W}$ (original magnification: $\times 400$ ). The data presented as means \pm SEM. ${ }^{*} p<0.05,{ }^{*} p<0.01$ vs survivin at E15.5

confirmed the presence of the deleted allele in the pancreas of Pdxl Cre ${ }^{+}$Survivin $^{\mathrm{fl} / \mathrm{fl}}$ mice (Fig. 2c). Levels of survivin in other tissues, including the liver and kidney, were unaffected (Fig. 2d).

Pdxl Cre $^{+}$Survivin ${ }^{f l f l}$ mice display impaired glucose tolerance Pdxl Cre ${ }^{+}$Survivin $^{\mathrm{fl} / \mathrm{fl}}$ mice were born at expected Mendelian frequencies and survived past weaning. Body weights and pancreatic weights were not different from littermate controls at P1 and postnatal week 3 (Electronic supplementary material [ESM] Fig. 1), suggesting that survivin is not required for gross pancreatic development and that the absence of survivin does not significantly impair the function or normal growth of the pancreas.

To determine the effect of Survivin deletion on islet beta cell function, we measured blood glucose levels in $P d x I$ $\mathrm{Cre}^{+}$Survivin $^{\mathrm{fl} / \mathrm{fl}}$ mice. Fasting blood glucose levels gradually increased with age in mutant mice compared with those in control littermates, and became significantly higher than those in controls at 6 months of age (Fig. 3a). IPGTTs were 


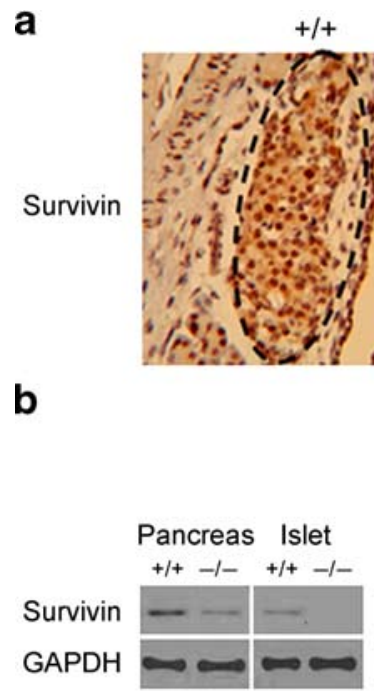

Fig. 2 Pancreas-specific deletion of Survivin. a Immunohistochemistry showing Survivin deletion in pancreatic islet cells at P1 from $P d x 1$ $\mathrm{Cre}^{+}$Survivin ${ }^{\mathrm{fl} / \mathrm{fl}}$ mice (original magnification: $\times 400$ ). b Western blots and quantification showing decreased levels of survivin in the pancreas and isolated islets from $P d x l \operatorname{Cre}^{+}$Survivin $^{\mathrm{fl} / \mathrm{fl}}$ mice $(n=5$
C
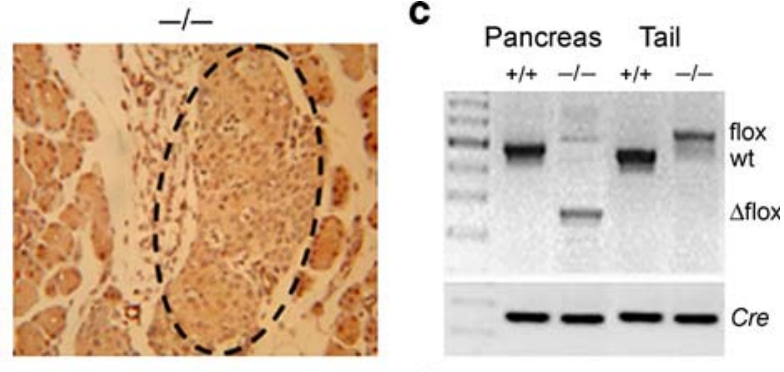

d

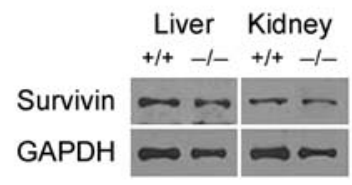

performed when the mice were 3 and 8 weeks of age. The mutant mice showed similar glucose tolerance to the controls at postnatal week 3 (Fig. 3b). At 8 weeks, however, the mutant mice exhibited markedly higher glucose excursions (Fig. 3c). To further understand this process, we assessed beta cell function by GSIS and fasting insulin levels at postnatal week 8 . The fasting insulin levels were significantly decreased (Fig. 3d), and insulin secretion in response to an i.p. glucose challenge was markedly compromised in the mutant mice (Fig. 3e). ITT did not show any differences in peripheral insulin sensitivity in these mice (Fig. 3f), supporting that the lower fasting insulin is not in response to an increase in peripheral insulin sensitivity, but rather from the inadequate supply of insulin from the beta cells. Similarly, glucose intolerance in older mutant mice is likely due to the significant defect in insulin secretion.

Pancreatic Survivin deletion leads to decreased beta cell mass To further explore the effects of survivin on beta cells, we examined pancreatic islet morphology. From E18.5 to 2 months of age, beta cell mass was significantly decreased in Pdxl Cre ${ }^{+}$Survivin $^{\mathrm{fl} / \mathrm{fl}}$ mice compared with controls (Fig. 4a). However, alpha cell mass was similar in the two groups at P1 and postnatal week 3 (Fig. 4b). A decrease in beta cell mass can result from a decline in beta cell number, in beta cell size, or both. We found that, at P1, total beta cell number was markedly decreased in the mutant mice compared with control mice $(p<0.05$, Fig. $4 \mathrm{c})$, while beta cell size was similar in the two groups (Fig. 4d). Serial pancreatic sections obtained at P1 showed that the survivin- per genotype). c PCR analysis of Cre-mediated recombination of the Survivin locus $(\Delta$ flox) in pancreas and tail tissue. $\mathbf{d}$ Levels of survivin in the liver and kidney are unchanged. $+/+, P d x l \mathrm{Cre}^{+}$Survivin $^{+/+}$ mice; -l-, Pdxl Cre Survivin $^{\mathrm{fl} / \mathrm{fl}}$ mice; wt, wild type; The data presented as means \pm SEM. $* * p<0.01 \mathrm{vs}+/+$

deficient cells had many enlarged, dysmorphic nuclei, characterised by an increase in nuclear size that was not apparent in the control cells (mean nuclear size $37.9 \pm 1.3 \mathrm{vs}$ $30.4 \pm 1.4 \mu^{2}, p<0.01$; Fig. $4 \mathrm{e}$ ). This phenotype is similar to that described after homozygous deletion of Survivin in murine embryonic cells during early embryogenesis [15].

To further confirm our findings of essential roles of survivin in pancreatic islets, we employed another knockout mouse model with rat insulin promoter (RIP)-driven Survivin deletion in pancreatic beta cells (ESM Fig. 2a-d). RIP Cre ${ }^{+}$Survivin $^{f l / l}$ mice also exhibited a significant decrease in beta cell mass at $\mathrm{P} 1$ and displayed glucose intolerance at 2 months of age (ESM Fig. 2e, f), similar to the results obtained from $P d x I$ $\mathrm{Cre}^{+}$Survivin ${ }^{f l f l}$ mice. Thus, the absence of survivin in the pancreas or the beta cells leads to a decline in beta cell mass.

The decreased beta cell mass in the mutant mice was not accompanied by evidence of abnormal islet development. When the mice were examined at $\mathrm{P} 1$ or at 2 months of age, the distribution and proportions of beta and alpha cells were normal (Fig. 5). Their islet microvasculature was intact (Fig. 5), and there were no differences in beta cell differentiation markers such as GLUT-2 and PDX1 between the two genotypes (Fig. 5). Thus, Survivin deletion in the pancreas leads to a defect in beta cell mass throughout the late embryonic and postnatal periods without a significant defect in islet development.

Cell proliferation is defective in survivin-deficient islets In order to elucidate the specific cellular processes that resulted in a decreased beta cell mass in the survivin 
a

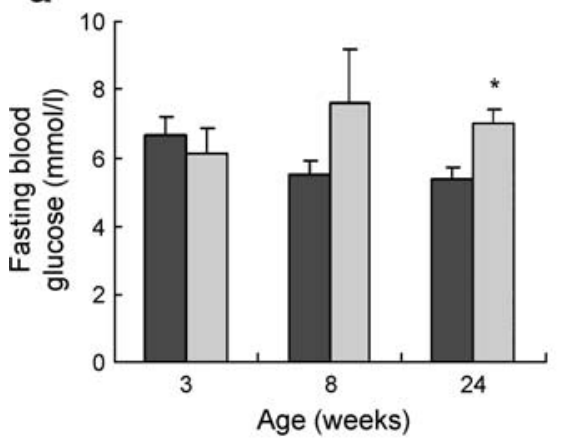

d

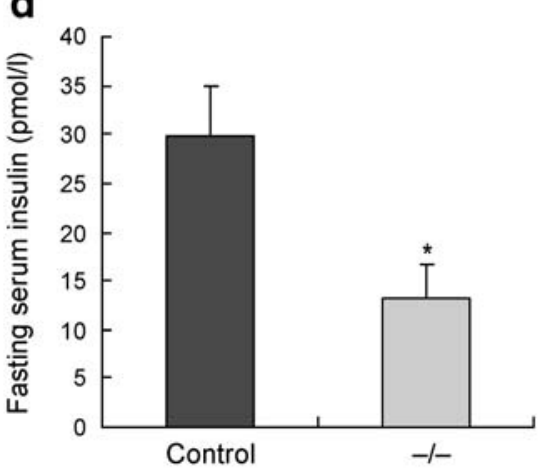

b

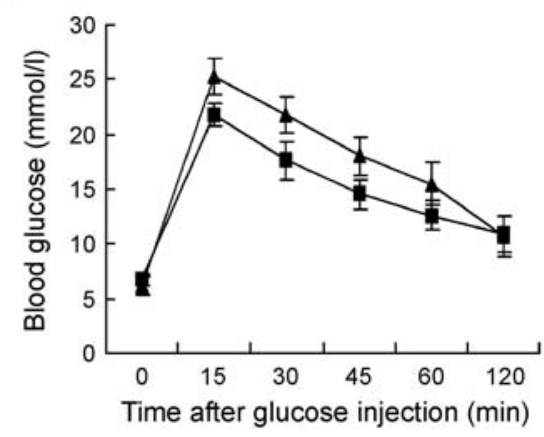

e

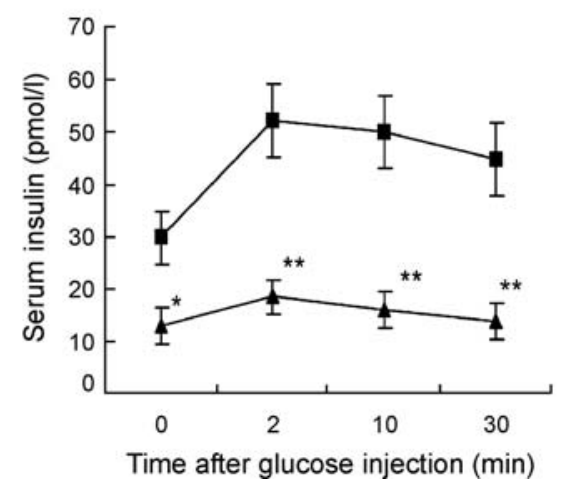

C

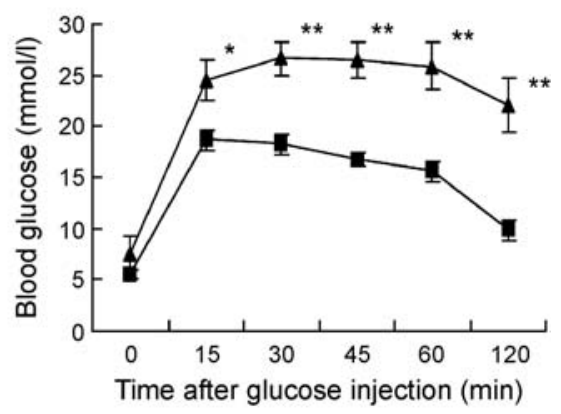

f

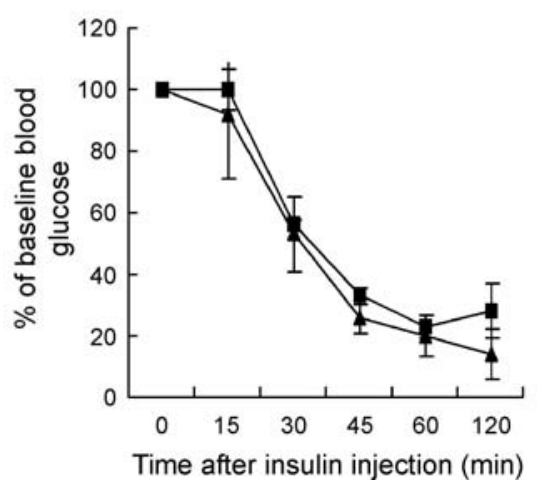

Fig. 3 Absence of survivin leads to age-dependent glucose intolerance. a Fasting blood glucose levels gradually increased with age in $P d x 1$ Cre $^{+}$Survivin $^{\mathrm{fl} / \mathrm{fl}}$ mice (grey bars) compared with those in littermate controls (black bars) ( $n=8$ per genotype). b An IPGTT performed at 3 weeks of age shows similar responses for the $P d x 1$ $\mathrm{Cre}^{+}$Survivin $^{\mathrm{fl} / \mathrm{fl}}$ group (triangles) and the control group (squares) $(n=$ 8 per genotype). c At 8 weeks of age, the $P d x 1 \mathrm{Cre}^{+}$Survivin $^{\mathrm{fl} / \mathrm{fl}}$ (triangles) mice exhibit markedly higher glucose excursions during an IPGTT compared with controls (squares) ( $n=8$ per genotype). d At 8 weeks, fasting insulin levels in $P d x 1 \mathrm{Cre}^{+}$Survivin $^{\mathrm{fl} / \mathrm{fl}}$ mice $(-/-)$ are significantly lower than those in controls ( $n=10$ per genotype). e In vivo glucose-stimulated insulin secretion after i.p. glucose injection is markedly compromised in $\mathrm{Pdxl} \mathrm{Cre}^{+}$Survivin $^{\mathrm{fl} / \mathrm{fl}}$ mice (triangles) compared with that in controls (squares) $(n=10$ per genotype; age, 8 weeks). f Insulin tolerance tests demonstrate similar insulin sensitivity in Pdxl $\mathrm{Cre}^{+}$Survivin $^{\mathrm{fl} / \mathrm{fl}}$ mice (triangles) and controls (squares) ( $n=3$ per genotype; age 8 weeks). The control group includes Pdxl Cre $e^{+}$Survivin $^{+++}$mice and $\mathrm{Pdxl} \mathrm{Cre}^{+}$Survivin $^{\mathrm{fl} /+}$ mice. The data presented as means \pm SEM. ${ }^{*} p<0.05,{ }^{* *} p<0.01$ vs control

Levels of phosphorylated RB were significantly decreased, which was consistent with the non-phosphorylated RB, which is active and mediates cell cycle inhibition [29, 30]. We also observed a decrease in levels of cyclin-E and CDK2 proteins associated with progression of the $\mathrm{S}$ phase. Interestingly, levels of the cell cycle inhibitors p21 and p27 were also decreased, with a concomitant decline in caspase-3 levels observed (Fig. 6d). We have previously shown that caspase-3 cleaves p21 and p27, and p21 serves not only as a cell cycle inhibitor, but also as a promoter of cell cycle progression $[31,32]$. Furthermore, p21 can promote mitosis by forming a complex with caspase-3 and survivin [33]. Therefore, in the absence of survivin, a decrease in p21 and caspase- 3 levels may lead to defective mitosis. Levels of Aurora B kinase, which binds to survivin to form the chromosomal passenger complex, were also decreased in the survivin-deficient islets (Fig. 6d). No significant changes in levels of CDK4 or cyclin-D were noted (Fig. 6d). We also explored the insulin signalling pathways that play an important role in regulating

To further characterise the cell cycle abnormalities, we examined the production of cell cycle-regulating proteins. 

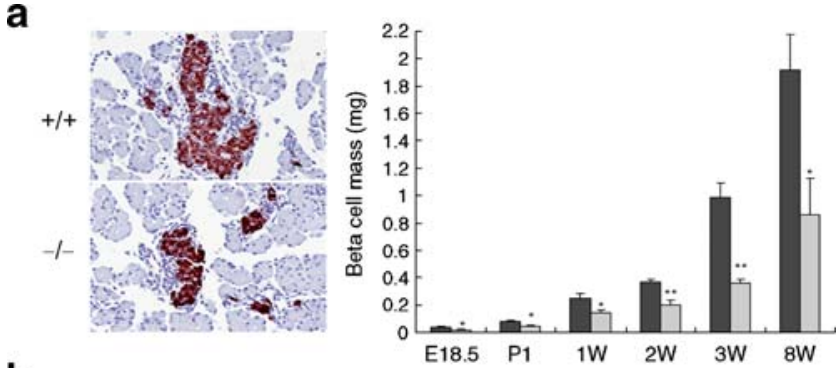

b
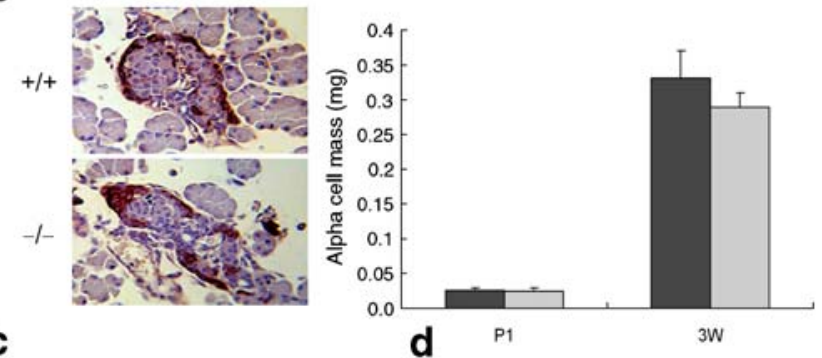

C
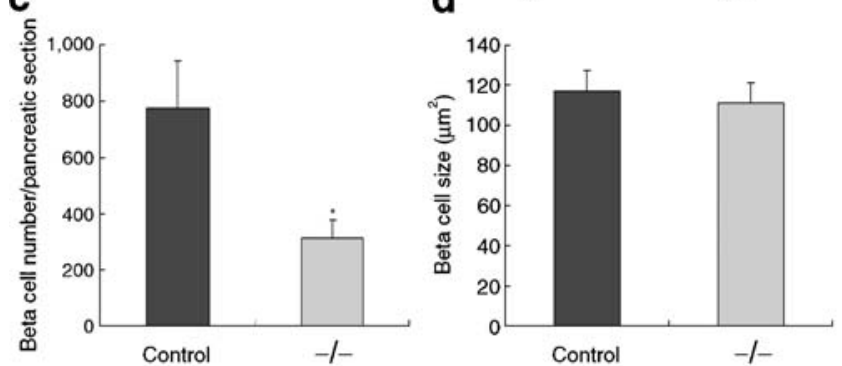

e
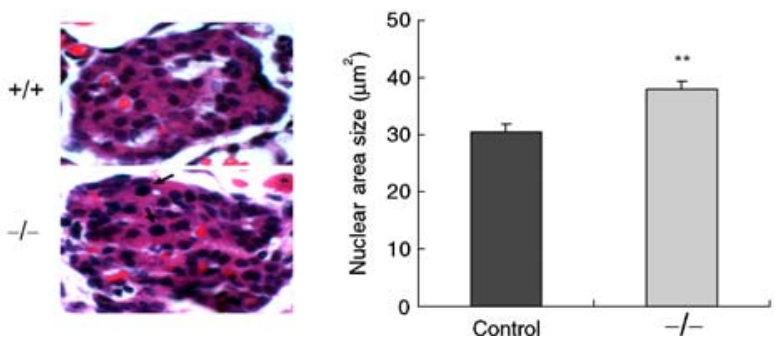

Fig. 4 Survivin deletion from the pancreas leads to decreased beta cell mass. a Immunohistochemistry of representative pancreatic sections showing insulin-positive cells in Pdxl Cre Survivin $^{\mathrm{fl} / \mathrm{fl}}(-/-)$ and wild-type mice $(+/+)$ at P1 (original magnification: $\times 200)$ ). Quantification analysis reveals a significant decline in the beta cell mass of the mutant mice (grey bars) relative to the control mice (black bars) from E18.5 to 8 weeks $(8 \mathrm{~W})$ of age ( $n \geq 3$ per genotype at each time point). b Immunohistochemistry of representative pancreatic sections showing glucagon-positive cells in Pdxl Cre ${ }^{+}$Survivin $^{\text {fl/fl }}$ mice and wildtype mice at P1 (original magnification: $\times 200$ ). Quantification analysis reveals a similar alpha cell mass in both the mutant mice (grey bars) and wild-type mice (black bars) at P1 and 3 weeks of age ( $n \geq 3$ per genotype). c At P1, total beta cell number is markedly decreased in the mutant mice compared with littermate controls ( $n=5$ per genotype), but beta cell size (d) is similar in the two groups ( $n=5$ per genotype). $\mathbf{e}$ Haematoxylin and eosin staining of pancreatic sections from control and mutant mice at P1. Mutant beta cells with enlarged nuclei are indicated by arrows (original magnification: $\times 400$ ). Nuclear size measurements show an increase in nuclear size in mutant cells. The data presented as means \pm SEM. ${ }^{*} p<0.05,{ }^{*} p<0.01$ vs control
Inuslin/glucagon
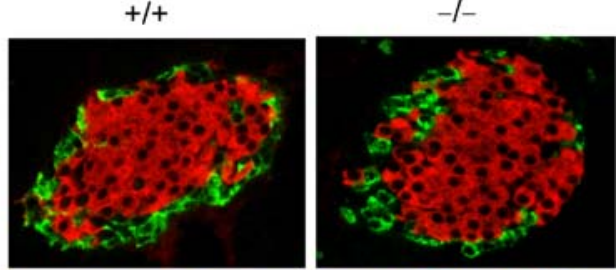

von Willebrand factor
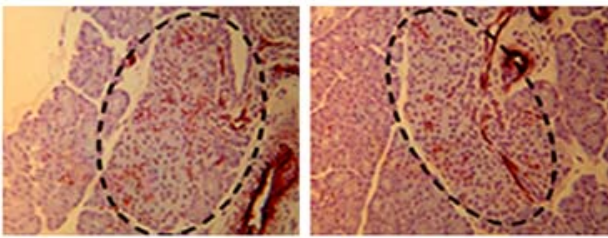

GLUT2
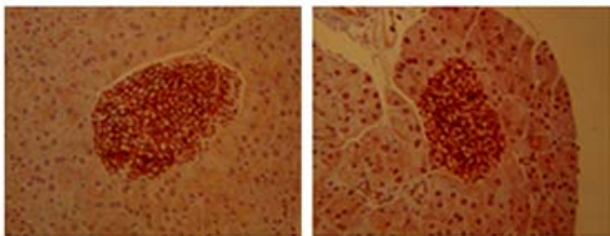

PDX1
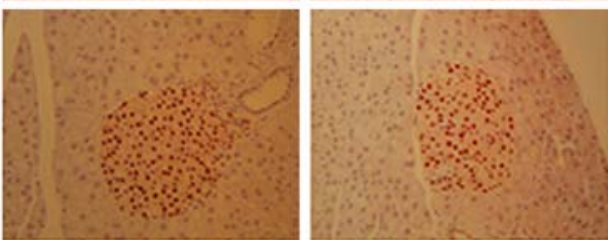

Fig. 5 Islet development in $P d x 1 \mathrm{Cre}^{+}$Survivin $^{\mathrm{fl} / \mathrm{fl}}$ mice (-/-) and wild-type mice $(+/+)$. Insulin- and glucagon-positive cells showing normal distribution and proportions of beta and alpha cells at P1 (original magnification: $\times 400$ ). Staining of von Willebrand factor shows intact islet microvasculature in 2-month-old mice (original magnification: $\times 400$ ). The dotted line indicates an intact islet. GLUT2 and PDX1 are normally present in the cytoplasmic membrane and nucleus of beta cells, respectively, in 2-month-old mice (original magnification: $\times 400$ )

beta cell proliferation. Levels of phosphorylated Akt were significantly decreased in the survivin-deficient islets, while levels of ERK1/2 and mTOR were similar in both groups (Fig. 6e), indicating that survivin may be an essential mediator of the regulation of beta cell proliferation by the phosphatidylinositol 3-kinase-AKT pathway.

To address the question of whether survivin is required for glucagon-like peptide-1 (GLP1)-induced beta cell proliferation, we treated the 2-week-old mice with exendin-4, a long acting GLP1 receptor agonist. After twice daily injection for 3 days, beta cell proliferation was significantly increased in the mutant and control groups (1.7- and 1.5-fold from baseline, respectively) (Fig. 6f). Taken together, our findings show that survivin is essential for cell cycle regulation in pancreatic islets during physiological growth of the islets; however, survivin is not required for GLP1-induced proliferation.

Apoptosis is not increased in survivin-deficient islets To elucidate whether an increase in cell death contributed to the decreased beta cell mass in survivin-deficient islets, we examined beta cell apoptosis in islets at P1 and postnatal 
Fig. 6 Survivin-deficient islets show defects in cell proliferation. a Representative Ki67 and insulin staining of consecutive pancreatic sections and quantification shows decreased beta cell proliferation at $\mathrm{P} 1$ and 2 months of age in $\mathrm{Pdxl} \mathrm{Cre}^{+}$Survivin ${ }^{\mathrm{fl} / \mathrm{fl}}$ mice $(-/-)$ relative to control mice $(+/+)$ (original magnification: $\times 400 ; n=5$ per genotype at each time point). ${ }^{*} p<0.05$ vs control; $* * p<0.01$ vs P1. Aberrant cell cycle progression in islets of survivin-deficient mice (c) compared with wild-type mice (b) at 2 weeks of age ( $>4 \mathrm{~N}: 7.2 \pm 1.1 \%$ vs $3.1 \pm 0.2 \%$, $p<0.01$; S: $3.2 \pm 0.2 \%$ vs $5.0 \pm$ $0.3 \%, p<0.01 ; \mathrm{G} 2 / \mathrm{M}: 12.3 \pm$ $0.3 \%$ vs $14.3 \pm 0.3 \%, p<0.05$; $\mathrm{G} 0 / \mathrm{G} 1: 77.4 \% \pm 1.3 \%$ vs $77.6 \% \pm 0.4 \%, p>0.05 ; n=10$ per genotype). d Western blots and quantification show perturbations in cell cycle proteins of islets of survivin-deficient mice compared with wild-type mice at 2 weeks of age $(n \geq 3$ per genotype). $p<0.05, p<0.01$ vs control. Aurora BK, Aurora B kinase. e Western blots and quantification show perturbations in the phosphatidylinositol 3-kinase signalling pathway in cell cycle proteins of islets of survivin-deficient mice compared with wild-type mice at 2 weeks of age ( $n \geq 3$ per genotype). $* * p<0.01$ vs control. p-, phosphorylated. f Beta cell proliferation induced by exendin-4 (grey bars) and standard conditions (PBS, white bars) in $\mathrm{Pd} x \mathrm{l} \mathrm{Cre}^{+}$Survivin $^{\mathrm{fl} / \mathrm{fl}}$ mice and wild-type mice at 2 weeks of age $(n=3$ per genotype). The data are presented as means \pm SEM. $* p<0.05$ vs PBS a

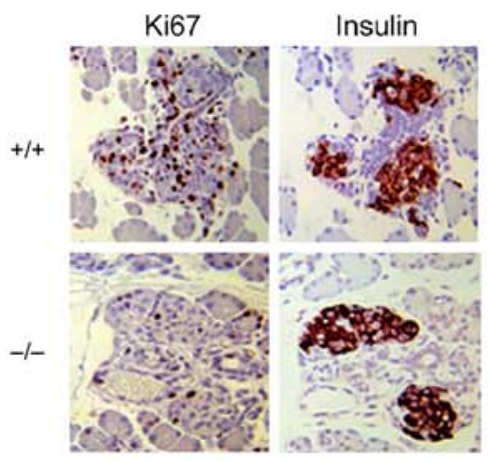

b

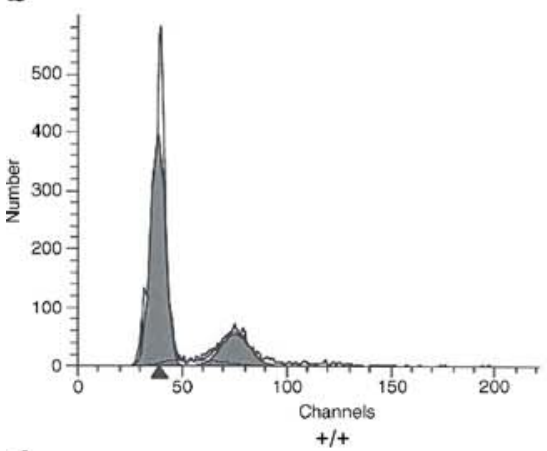

C
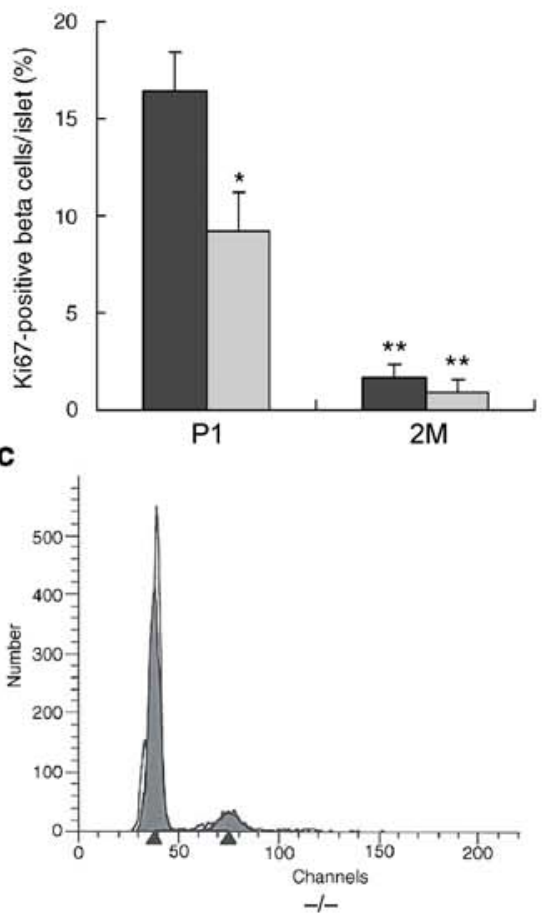

d
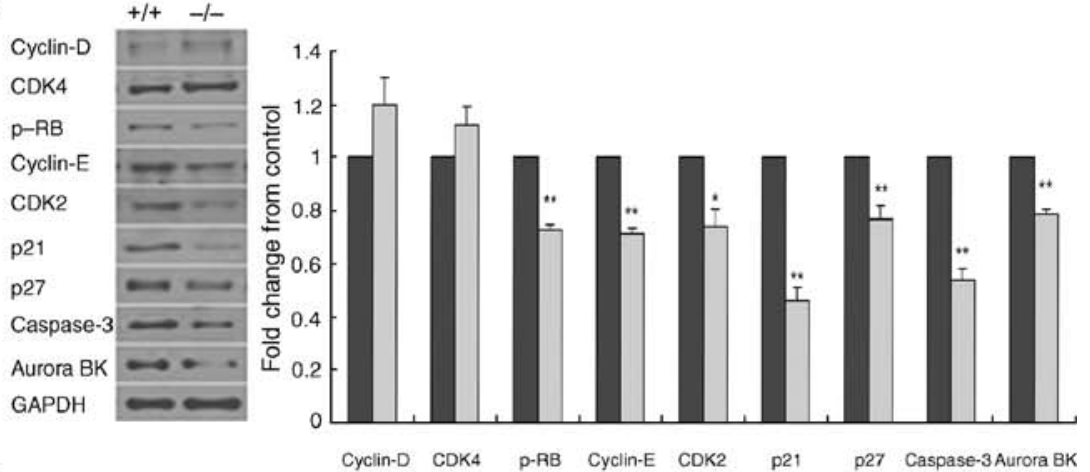

e
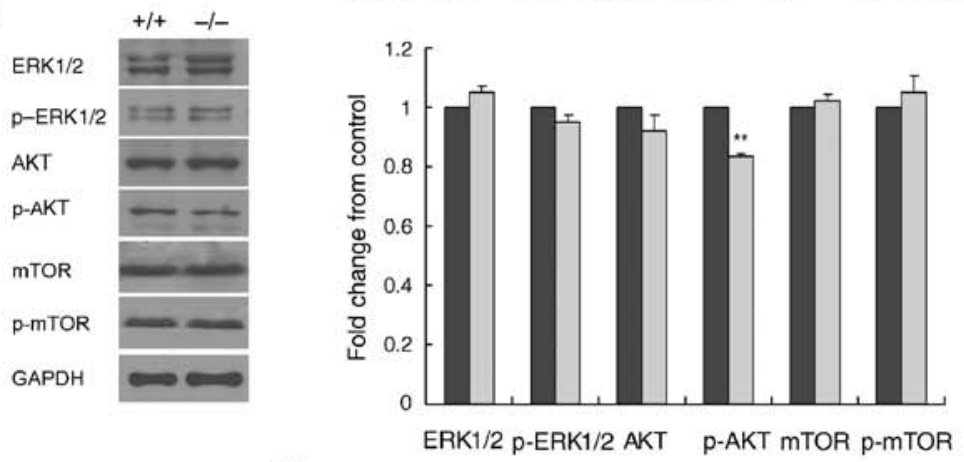

f

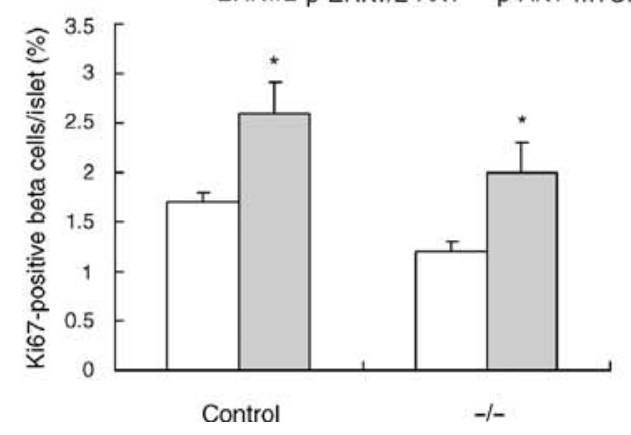


week 3. At both time points, the rate of apoptosis was low and not significantly different between Pdxl Cre ${ }^{+}$Survivin $^{\mathrm{fl} / \mathrm{fl}}$ mice and littermate controls (Fig. 7a). Furthermore, we did not detect any significant changes in apoptosis-related proteins, such as cleaved caspase-3, BAD, phosphorylated $\mathrm{BAD}, \mathrm{BCL}-\mathrm{XL}$ and p53 in the islets of 2-week-old mutant mice compared with controls (Fig. 7b). To examine whether survivin-deficient islets would be more sensitive to apoptosis during diabetes development, we used the experimental diabetes model induced by MLDS in 2-week-old mice [34]. The mutant mice and littermate controls were similarly susceptible to the development of diabetes after MLDS injections (Fig. 7c). Examination of the pancreases following diabetes induction revealed dramatically decreased beta cell mass and higher rates of beta cell apoptosis in MLDS-treated mice, with no significant difference between the two groups (Fig. 7d,e), suggesting that survivin-deficient islets are not more susceptible to MLDS-induced apoptosis.

\section{Discussion}

In this study, we have comprehensively analysed the pattern of survivin levels in islets over the late embryonic and postnatal period, and defined the essential physiological role of survivin in the determination of pancreatic beta cell mass. From the second wave of pancreatic endocrine development at E15.5 to postnatal week 3, survivin was expressed within the pancreases of mice. From E15.5 to E18.5, immunoreactivity to survivin consistently decreased. However, survivin levels rebound late in embryogenesis (from E18.5 to P1), and then gradually decreased again during the postnatal period (from P1 to postnatal week 3). This characteristic pattern of survivin levels coincides with a transient burst of beta cell proliferation (from E18.5 to immediately after birth) followed by an increase in beta cell apoptosis and neogenesis, and a progressive decrease in beta cell replication in the neonatal period $[1,3,5,6]$. Given the multi-regulatory role of survivin in all of these cellular processes, we hypothesised that survivin is a critical regulator of pancreatic beta cell mass during this remodelling period.

To dissect the physiological significance of survivin in the regulation of beta cell mass, we generated a $P d x 1$ promoterdriven Survivin knockout mouse. The tissue-specific deletion of Survivin in the pancreas resulted in a decrease in pancreatic beta cell mass throughout the perinatal period. The compromised beta cell mass was associated with a progressive decline in glucose tolerance with age. At 3 weeks of age, blood glucose levels were similar between the two groups. However, at 2 months of age, the mutant mice developed overt glucose intolerance. A possible explanation is that the compromised beta cell mass can still maintain sufficient insulin production in response to maternal milk containing low levels of carbohydrates, whereas, after weaning, it can no longer produce sufficient insulin to meet the increasing demand in response to the high carbohydrate in the standard chow diet.

The molecular mechanisms underlying the decrease in pancreatic beta cell mass in survivin-deficient mice was due to a defect in cell cycle progression. During G1, Survivin transcription increases and reaches a peak in G2/M [35, 36]. During mitosis, survivin functions in a narrow time window at metaphase and anaphase. As a chromosomal passenger protein, survivin is involved in chromosome segregation, central spindle formation, cytokinesis and spindle checkpoint maintenance through its interactions with other passenger proteins, inner centromere protein and Aurora B kinase [37]. In addition, survivin has been shown to co-localise with caspase-3 and p21 at the centrosome during mitosis [33]. Thus, disruption of survivin may lead to the loss of caspase-3 and p21, and unbalanced CDK2 activity, leading to abnormal centrosome duplication and formation of multipolar spindles, multinucleation and polyploidy. In keeping with these observations, our in vivo data revealed that survivin-deficient cells had many enlarged, dysmorphic nuclei, characterised by an increase in nuclear size. An excess of cells with $>4 \mathrm{~N}$ modal chromosome numbers was detected in the survivin-deficient islets, together with decreased expression of caspase-3 and p21. Moreover, we revealed perturbations in cell cycle proteins, phosphorylated RB, cyclin-E, CDK2, p27 and Aurora B kinase, which may have contributed to the delay of the cell cycle in the $\mathrm{S}$ and $\mathrm{G} 2 / \mathrm{M}$ phases. In addition, levels of phosphorylated Akt were significantly decreased in the survivin-deficient islets, indicating that the phosphatidylinositol 3-kinase-AKT pathway may be involved in survivinmediated beta cell proliferation.

The gut-derived insulinotropic hormone GLP1 and its long-acting agonist, exendin-4, are a new class of agents for the treatment of type 2 diabetes [38]. Exendin-4 could stimulate both beta cell replication and neogenesis from ductal progenitor cells, and inhibit apoptosis of beta cells $[39,40]$. Our data show that the presence of survivin is not an essential mediator of the proliferative effects of exendin-4.

In addition to promoting cell division, survivin has been shown to be an inhibitor of apoptosis [33, 41]. Although the loss of survivin in many cancer cell lines has been associated with apoptosis, the protein is not essential for the survival of normal cells [42]. Our in vivo study did not show a significant difference in the number of TUNEL-positive cells in survivin-deficient islets at P1 and at postnatal week 3. Furthermore, we did not detect any significant changes of apoptosis-related proteins such as cleaved caspase-3, BAD, phosphorylated BAD and BCL-XL in islets of 2-week-old mutant mice. Even during diabetes development, induced by 
Fig. 7 Apoptosis in survivindeficient islets. a TUNEL assay of representative pancreas sections (original magnification: $\times 400$; apoptotic beta cells are indicated by arrows) and quantification show low rate of beta cell apoptosis at $\mathrm{P} 1$ and 3 weeks ( $3 \mathrm{~W}$ ) of age with no significant difference between Pdxl Cre Survivin ${ }^{\mathrm{fl} / \mathrm{fl}}$

mice (-/-, grey bars) and littermate controls $(+/+$, black bars) $(n=5$ per genotype). b Western blots and quantification show similar changes in apoptosisrelated proteins islets of survivin-deficient mice $(-/-$, grey bars) and controls $(+/+$, black bars) in 2-week-old mice ( $n \geq 3$ per genotype).

c Random blood glucose levels in $\mathrm{Pdxl} \mathrm{Cre}^{+}$Survivin $^{\mathrm{fl} / \mathrm{fl}}$ mice (grey bars) and littermate controls (black bars) at 2 weeks of age treated with streptozotocin (STZ; $40 \mathrm{mg} / \mathrm{kg}$ body weight) for five consecutive days ( $n=8$ per genotype). ${ }^{*} p<$ $0.05, * * p<0.01$ vs baseline.

d Similar significant decline in beta cell mass in mice 4 weeks after streptozotocin injection (black bars) compared with citrate buffer injection (grey bars) ( $n=5$ per genotype). ${ }^{\dagger} p<0.01$ vs control mice; $* * p<0.01$ vs citrate buffer injection. e Representative insulin and TUNEL co-staining and quantification show similar increases in apoptotic beta cells between the mutant mice and littermate controls after streptozotocin injection (black bars) relative to citrate buffer injection (grey bars) ( $n=5$ per genotype). The data are presented as means \pm SEM. ${ }^{*} p<0.05$ vs citrate buffer injection a
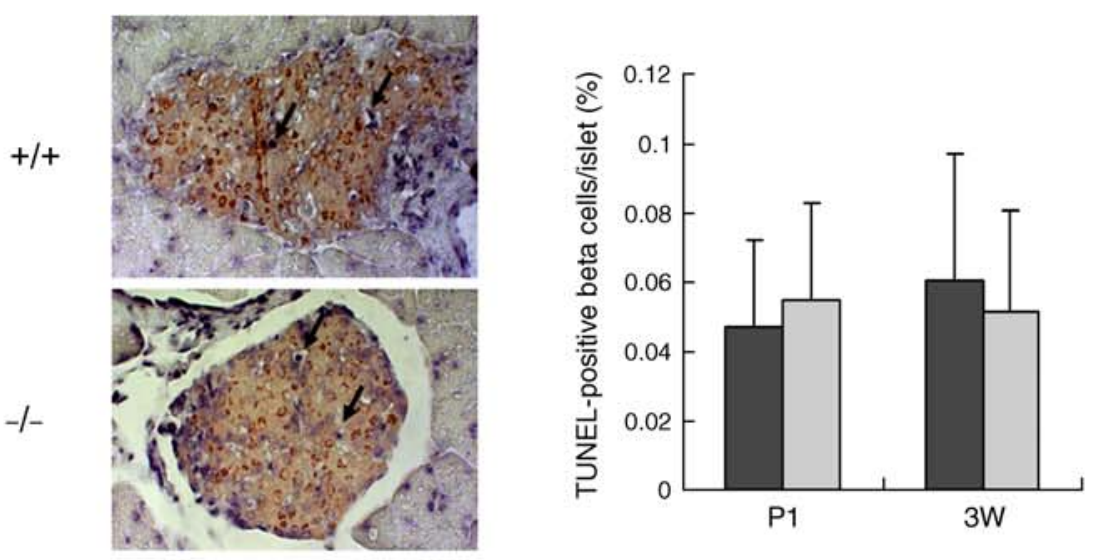

b

\section{Cleaved}

Caspase 3

BAD

p-BAD

$$
+/+\quad-1-
$$
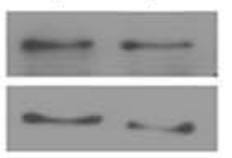

BCL-XL

p53

GAPDH
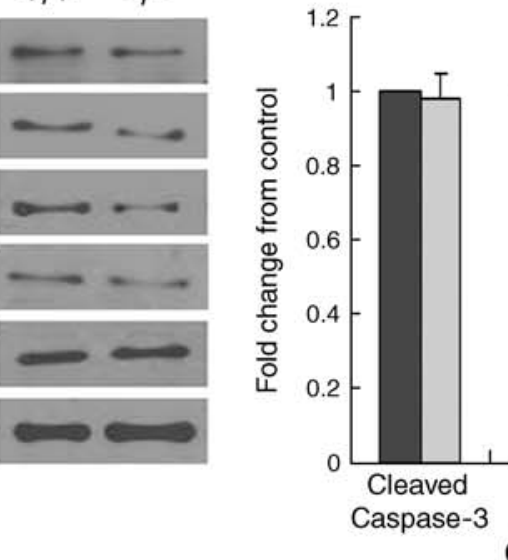

C

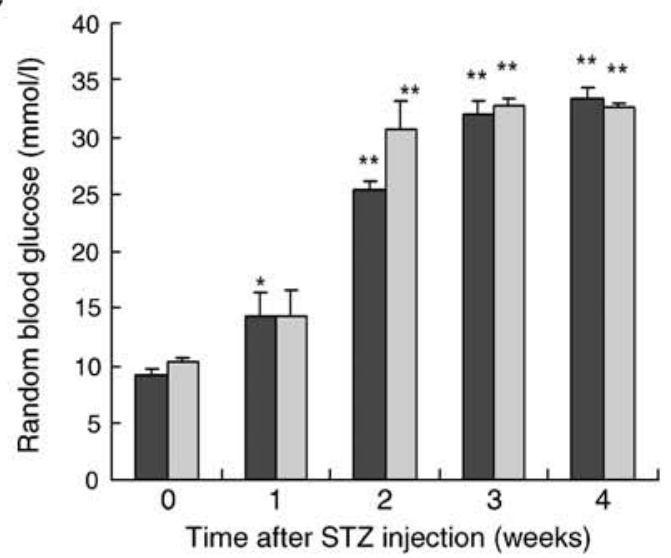

d

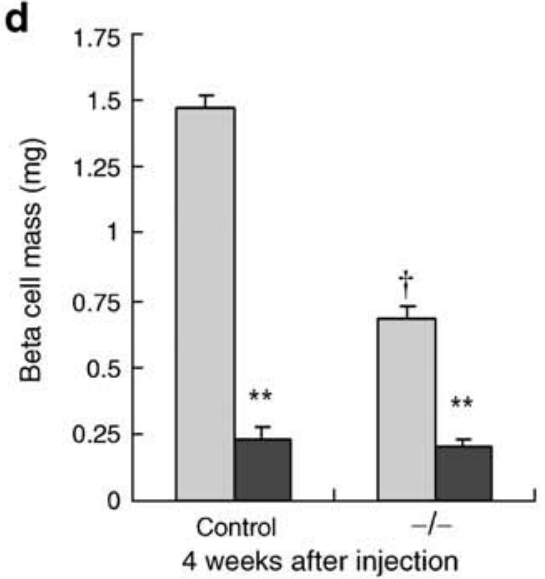

e

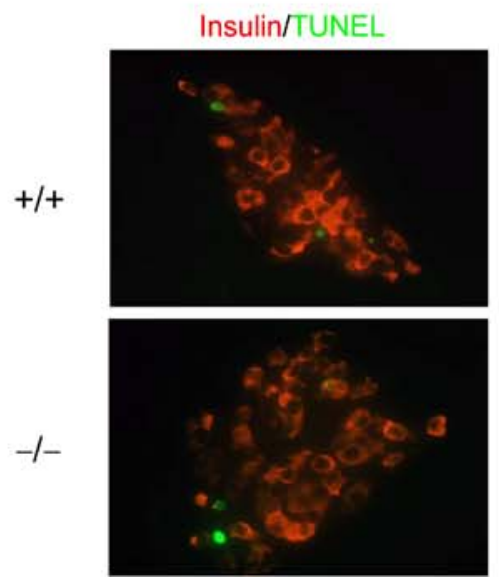

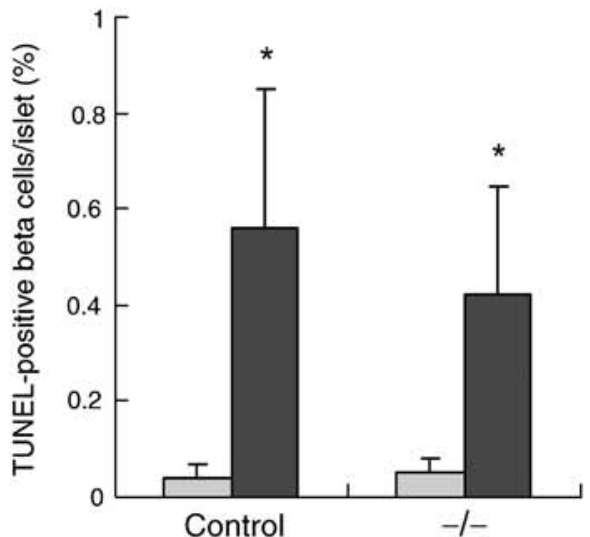


MLDS, the mutant mice and their littermate controls were equally susceptible to apoptosis, and survivin deficiency did not lead to a higher incidence, or more rapid onset, of diabetes. Collectively, these data suggest that survivin does not play a significant role in islet cell apoptosis.

During the preparation of our manuscript, we noted work by Jiang et al., which reported similar findings regarding the role of survivin in the pancreas [43]. In their model, tissuespecific deletion of Survivin in pancreatic endocrine cells was driven by the Pax6 promoter. Despite the different experimental model used by Jiang et al., their results were strikingly similar to ours with respect to the decrease in beta cell mass after birth and glucose intolerance by 4 weeks of age. There were, however, notable differences between the two studies. While Jiang and colleagues did not identify discernible effects of survivin on beta cell mass during embryogenesis, we found a significant reduction in beta cell mass in our mutant mice during the late embryonic period. Moreover, Jiang et al. observed a twofold increase in caspase-3 activity in the survivin-deficient islets of 1 - to 2-week-old animals, whereas we did not note a significant difference in apoptosis at these time points. These differences may be due to the different genetic models perhaps affecting susceptibility to apoptosis, which may be determined by the time during pancreatic development at which Survivin was deleted, or a difference in the genetic background of the mice, or a difference in the efficacy of Survivin deletion from islets in the two studies. A previous in vitro study has shown that, in at least some euploid human cells, survivin is essential for cellular proliferation but not for cell survival [42]. In keeping with our data on islets, the essential role of survivin in cell cycle regulation in the absence of an essential effect on apoptosis has also been shown in T cells [44].

Together, our data show that survivin deficiency in the pancreas leads to defects in beta cell mass establishment during the perinatal remodelling period, which leads to a permanent decrease in beta cell mass. The transient production of survivin during this remodelling period is therefore critical in determining beta cell mass early in life, and this cannot be compensated at a later time. Our data suggest that a critical beta cell mass must be reached during this perinatal period for the beta cells to adequately proliferate and continue to grow in response to the body's demand for insulin. Recent gene inactivation and overexpression studies have shown that cell cycle regulators such as CDK4, cyclin-D2, p16, p27 and forkhead box M1 (FOXM1) play an essential role in regulating beta cell mass in the postnatal period [45-49]. Our data show that the precise time during which these genes are expressed may be an important factor in reaching the necessary $\beta$-cell mass to provide an adequate supply of insulin. These results have therapeutic implications for the expansion of beta cells in the setting of diabetes treatment and islet transplantation.
Acknowledgements This work was supported by grants to M. Woo from the Canadian Institutes of Health Research and the Canadian Diabetes Association. X. Wu is supported by the Jiangsu Government Scholarship for Overseas Studies and a grant from the Science Foundation of Jiangsu Province (grant no. BK2007251). We are grateful for the generous gift of the $P d x l$ Cre mice from the laboratory of D. A. Melton (Department of Molecular and Cellular Biology, and Howard Hughes Medical Institute, Harvard University, Cambridge, MA, USA) and for the technical advice provided by R. Wang (Department of Physiology and Pharmacology, University of Western Ontario, London, ON, Canada) on isolating islets from 2- to 3-week-old mice.

Duality of interest The authors declare that there is no duality of interest associated with this manuscript.

\section{References}

1. Scaglia L, Cahill CJ, Finegood DT, Bonner-Weir S (1997) Apoptosis participates in the remodeling of the endocrine pancreas in the neonatal rat. Endocrinology 138:1736-1741

2. Bonner-Weir S (2000) Life and death of the pancreatic beta cells. Trends Endocrinol Metab 11:375-378

3. Bonner-Weir S (2000) Perspective: postnatal pancreatic beta cell growth. Endocrinology 141:1926-1929

4. Ackermann AM, Gannon M (2007) Molecular regulation of pancreatic beta-cell mass development, maintenance, and expansion. J Mol Endocrinol 38:193-206

5. Bernard-Kargar C, Ktorza A (2001) Endocrine pancreas plasticity under physiological and pathological conditions. Diabetes 50 (Suppl 1):S30-S35

6. Gannon M, Ables ET, Crawford L et al (2008) Pdx-1 function is specifically required in embryonic beta cells to generate appropriate numbers of endocrine cell types and maintain glucose homeostasis. Dev Biol 314:406-417

7. Finegood DT, Scaglia L, Bonner-Weir S (1995) Dynamics of betacell mass in the growing rat pancreas. Estimation with a simple mathematical model. Diabetes 44:249-256

8. Dor Y, Brown J, Martinez OI, Melton DA (2004) Adult pancreatic beta-cells are formed by self-duplication rather than stem-cell differentiation. Nature 429:41-46

9. Georgia S, Bhushan A (2004) Beta cell replication is the primary mechanism for maintaining postnatal beta cell mass. J Clin Invest 114:963-968

10. Srinivasula SM, Ashwell JD (2008) IAPs: what's in a name? Mol Cell 30:123-135

11. Ambrosini G, Adida C, Altieri DC (1997) A novel anti-apoptosis gene, survivin, expressed in cancer and lymphoma. Nat Med 3:917-921

12. Altieri DC (2008) New wirings in the survivin networks. Oncogene 27:6276-6284

13. Altieri DC (2008) Survivin, cancer networks and pathwaydirected drug discovery. Nat Rev Cancer 8:61-70

14. Mita AC, Mita MM, Nawrocki ST, Giles FJ (2008) Survivin: key regulator of mitosis and apoptosis and novel target for cancer therapeutics. Clin Cancer Res 14:5000-5005

15. Uren AG, Wong L, Pakusch M et al (2000) Survivin and the inner centromere protein INCENP show similar cell-cycle localization and gene knockout phenotype. Curr Biol 10:1319-1328

16. Okada H, Bakal C, Shahinian A et al (2004) Survivin loss in thymocytes triggers p53-mediated growth arrest and p53independent cell death. J Exp Med 199:399-410

17. Jiang Y, de Bruin A, Caldas $H$ et al (2005) Essential role for survivin in early brain development. J Neurosci 25:6962-6970 
18. Leung CG, Xu Y, Mularski B, Liu H, Gurbuxani S, Crispino JD (2007) Requirements for survivin in terminal differentiation of erythroid cells and maintenance of hematopoietic stem and progenitor cells. J Exp Med 204:1603-1611

19. Zwerts F, Lupu F, de Vriese A et al (2007) Lack of endothelial cell survivin causes embryonic defects in angiogenesis, cardiogenesis, and neural tube closure. Blood 109:4742-4752

20. Adida C, Crotty PL, McGrath J, Berrebi D, Diebold J, Altieri DC (1998) Developmentally regulated expression of the novel cancer anti-apoptosis gene survivin in human and mouse differentiation. Am J Pathol 152:43-49

21. Liggins C, Orlicky DJ, Bloomquist LA, Gianani R (2003) Developmentally regulated expression of survivin in human pancreatic islets. Pediatr Dev Pathol 6:392-397

22. Gu G, Dubauskaite J, Melton DA (2002) Direct evidence for the pancreatic lineage: NGN3+ cells are islet progenitors and are distinct from duct progenitors. Development 129:2447-2457

23. Nguyen KT, Tajmir P, Lin CH et al (2006) Essential role of Pten in body size determination and pancreatic beta-cell homeostasis in vivo. Mol Cell Biol 26:4511-4518

24. Wijesekara N, Konrad D, Eweida M et al (2005) Muscle-specific Pten deletion protects against insulin resistance and diabetes. Mol Cell Biol 25:1135-1145

25. Li Y, Cao X, Li LX, Brubaker PL, Edlund H, Drucker DJ (2005) $\beta$-Cell Pdx1 expression is essential for the glucoregulatory, proliferative, and cytoprotective actions of glucagon-like peptide-1. Diabetes 54:482-491

26. Liadis N, Murakami K, Eweida M et al (2005) Caspase-3dependent beta-cell apoptosis in the initiation of autoimmune diabetes mellitus. Mol Cell Biol 25:3620-3629

27. Stoffers DA, Heller RS, Miller CP, Habener JF (1999) Developmental expression of the homeodomain protein IDX-1 in mice transgenic for an IDX-1 promoter/lac Z transcriptional reporter. Endocrinology 140:5374-5381

28. Gannon M, Gamer LW, Wright CV (2001) Regulatory regions driving developmental and tissue-specific expression of the essential pancreatic gene $p d x 1$. Dev Biol 238:185-201

29. Buchkovich K, Duffy LA, Harlow E (1989) The retinoblastoma protein is phosphorylated during specific phases of the cell cycle. Cell 58:1097-1105

30. Ludlow JW, DeCaprio JA, Huang CM, Lee WH, Paucha E, Livingston DM (1989) SV40 large T antigen binds preferentially to an underphosphorylated member of the retinoblastoma susceptibility gene product family. Cell 56:57-65

31. Levkau B, Koyama H, Raines EW et al (1998) Cleavage of p21Cip1/ Waf1 and p27Kip1 mediates apoptosis in endothelial cells through activation of Cdk2: role of a caspase cascade. Mol Cell 1:553-563

32. Woo M, Hakem R, Furlonger C et al (2003) Caspase-3 regulates cell cycle in B cells: a consequence of substrate specificity. Nat Immunol 4:1016-1022
33. Li F, Ackermann EJ, Bennett CF et al (1999) Pleiotropic celldivision defects and apoptosis induced by interference with survivin function. Nat Cell Biol 1:461-466

34. Like AA, Rossini AA (1976) Streptozotocin-induced pancreatic insulitis: new model of diabetes mellitus. Science 193:415-417

35. Kobayashi K, Hatano M, Otaki M, Ogasawara T, Tokuhisa T (1999) Expression of a murine homologue of the inhibitor of apoptosis protein is related to cell proliferation. Proc Natl Acad Sci U S A 96:1457-1462

36. Li F, Altieri DC (1999) Transcriptional analysis of human survivin gene expression. Biochem J 344:305-311

37. Ruchaud S, Carmena M, Earnshaw WC (2007) Chromosomal passengers: conducting cell division. Nat Rev Mol Cell Biol 8:798-812

38. DeFronzo RA, Ratner RE, Han J, Kim DD, Fineman MS, Baron AD (2005) Effects of exenatide (exendin-4) on glycemic control and weight over 30 weeks in metformin-treated patients with type 2 diabetes. Diabetes Care 28:1092-1100

39. Xu G, Stoffers DA, Habener JF, Bonner-Weir S (1999) Exendin-4 stimulates both beta-cell replication and neogenesis, resulting in increased beta-cell mass and improved glucose tolerance in diabetic rats. Diabetes 48:2270-2276

40. Drucker DJ (2003) Glucagon-like peptides: regulators of cell proliferation, differentiation, and apoptosis. Mol Endocrinol 17:161-171

41. Li F, Ambrosini G, Chu EY et al (1998) Control of apoptosis and mitotic spindle checkpoint by survivin. Nature 396:580-584

42. Yang D, Welm A, Bishop JM (2004) Cell division and cell survival in the absence of survivin. Proc Natl Acad Sci U S A 101:15100-15105

43. Jiang Y, Nishimura W, Devor-Henneman D et al (2008) Postnatal expansion of the pancreatic beta-cell mass is dependent on survivin. Diabetes 57:2718-2727

44. Xing Z, Conway EM, Kang C, Winoto A (2004) Essential role of survivin, an inhibitor of apoptosis protein, in T cell development, maturation, and homeostasis. J Exp Med 199:69-80

45. Rane SG, Dubus P, Mettus RV et al (1999) Loss of Cdk4 expression causes insulin-deficient diabetes and Cdk4 activation results in beta-islet cell hyperplasia. Nat Genet 22:44-52

46. Kushner JA, Ciemerych MA, Sicinska E et al (2005) Cyclins D2 and D1 are essential for postnatal pancreatic beta-cell growth. Mol Cell Biol 25:3752-3762

47. Georgia S, Bhushan A (2006) p27 Regulates the transition of betacells from quiescence to proliferation. Diabetes 55:2950-2956

48. Krishnamurthy J, Ramsey MR, Ligon KL et al (2006) p16INK4a Induces an age-dependent decline in islet regenerative potential. Nature 443:453-457

49. Zhang H, Ackermann AM, Gusarova GA et al (2006) The FoxM1 transcription factor is required to maintain pancreatic beta-cell mass. Mol Endocrinol 20:1853-1866 